\title{
Salvage along the Red River: The Red Cox (3LA18) Site and its Place on the Caddo Landscape
}

\author{
Duncan P. McKinnon \\ University of Central Arkansas \\ Ryan Nguyen \\ Tyler Yeager \\ Leslie L. Bush \\ Heritage Research Center, Stephen F. Austin State University
}

Follow this and additional works at: https://scholarworks.sfasu.edu/ita

Part of the American Material Culture Commons, Archaeological Anthropology Commons, Environmental Studies Commons, Other American Studies Commons, Other Arts and Humanities Commons, Other History of Art, Architecture, and Archaeology Commons, and the United States History Commons

Tell us how this article helped you.

This Article is brought to you for free and open access by the Center for Regional Heritage Research at SFA ScholarWorks. It has been accepted for inclusion in Index of Texas Archaeology: Open Access Gray Literature from the Lone Star State by an authorized editor of SFA ScholarWorks. For more information, please contact cdsscholarworks@sfasu.edu. 
Salvage along the Red River: The Red Cox (3LA18) Site and its Place on the Caddo Landscape

\section{Creative Commons License}

\section{(c) (1) (8)}

This work is licensed under a Creative Commons Attribution-NonCommercial 4.0 International License 


\title{
Salvage along the Red River: The Red Cox (3LA18) Site and its Place on the Caddo Landscape
}

\author{
Duncan P. McKinnon ${ }^{1}$ \\ Ryan Nguyen ${ }^{1}$ \\ Tyler Yeager ${ }^{1}$ \\ Leslie L. Bush ${ }^{2}$ \\ ${ }^{1}$ University of Central Arkansas \\ ${ }^{2}$ Macrobotanical Analysis
}

The Red Cox (3LA18) site is located in Lafayette County, Arkansas along the Red River. As recounted in his weekly report of April 9, 1975, Dr. Frank Schambach received word that the site was being directly impacted by land leveling machinery. Salvage efforts collected the remains from the floor of a burned Caddo farmstead structure. Remains include ceramic sherds, carbonized corn kernels, acorn nutmeat and nutshells, burned wood fragments, and bits of daub. In this paper, we present the results of a recent analysis of the materials and situate the farmstead within the Red River landscape during a period shortly after Haley (ca. A.D. 1200 - 1400) phase and into the early part of the Belcher (ca. A.D. 1400 - 1700) phase.

\section{Introduction}

As part of a Spring 2016 directed study course at the University of Central Arkansas (UCA) on archeological lab methods, archeological remains from a Red River Caddo farmstead known as the Red Cox (3LA18) site were examined. While not numerous, the Red Cox material is significant because what little has been collected is all that remains of a farmstead site that was destroyed in the mid-1970s as a result of modern agricultural land modification. Importantly, the material documents one of the few identified farmsteads on the Caddo landscape and contributes to our knowledge of Caddo lifeways beyond those sites containing monumental earthen architecture. While there has been some important work identifying and excavating Red River farmsteads (e.g., Hemmings 1982; Kelley 1997; Trubowitz 1984), much of what we know today of Red River Middle-Late Caddo is from the perspective of larger sites that often contain mounds (e.g., Buchner et al. 2012; Jackson et al. 2012; McKinnon 2013; Webb 1959). As noted over thirty years ago by Dr. Frank Schambach (1982:7), there has been very little fieldwork on farmsteads. Since that time, these concerns still resonate largely because of the ephemeral character of farmstead sites, the damaging sinuosity of the meandering Red River, and the destructive nature of modern agricultural practices.

In this study, Red Cox material was analyzed and compared to select documented Caddo farmsteads located along the Red River, such as Cedar Grove (3LA97), McLelland (16BO236), Joe Clark (16BO237), and Spirit Lake/Cabinas (3LA83) (see Hemmings 1982; Kelley 1997; Trubowitz 1984). Several additional farmstead sites have been recorded along the Red River in this area although they remain unstudied or unpublished and their current status is unknown (see Hoffman 1970). From this analysis we situate the Red Cox farmstead within the Red River Great Bend landscape during a period shortly after Haley (ca. A.D. 1200 - 1400) phase and into the early part of the Belcher (ca. A.D. 1400 - 1700) phase.

\section{The Red River Great Bend Landscape}

The Great Bend region contains the Red River Valley along with "the upland watersheds of all minor tributaries of the Red River" (Schambach 1982:1). The landscape along the Red River is highly dynamic where many sites are situated within a broad alluvial river bottom floodplain defined by a type of topography known as ridge and swale (Guccione 1984, 2008). In this region numerous sites are subject to a high risk of seasonal flooding and destructive meandering (Schambach 1982:10). The area is abundant in fertile agricultural land and has proved to be an ideal locale for maize based agriculture during Caddo times (Perttula 2008). Today, and in more recent history, the region is dominated by mechanized production that requires substantial land modification, such as corn, rice, soybean, timber, and ranching activities. The current economy of the region certainly makes it challenging in terms of archeological preservation and is a contributing factor in the lack of documented farmstead sites.

Caddo settlement patterning along the Red

River during Middle-Late Caddo times is distinctive from various Mississippian period occupations situated further to the east that generally had a centralized 
earthen mound where structures existed within a palisaded area or in dense villages close to the mound center (e.g. Fowler 1997; King 2003; Knight and Steponaitis 1998). In contrast, Caddo settlement along the Red River consisted of a set of family farmsteads dispersed across the landscape with at least one supporting mound center and lacking a palisade enclosure. For example, the Domingo Terán de los Ríos map of 1691 displays a large Upper Nasoni community of several farmsteads dispersed along both sides of the Red River (Swanton 1942:Plate 1). Each partitioned farmstead consists of one or more large circular thatched-covered dwellings with open-air storage structures and ramadas. The community depicted in the Terán map likely represents the Hatchel-MitchellMoores site complex in present day Bowie County, Texas (Perttula 2005; Wedel 1978). The platform mound at the Hatchel site (41BW3) is considered the supporting temple mound (Perttula 2005; Wedel 1978). In addition to the large mound, a few of the dispersed farmsteads have been archeologically identified and recorded along this portion of the Red River (see Perttula et al. 1995; Perttula 2005; Walker and McKinnon 2012; Walker and Perttula 2008).

The Red Cox site represents a similar farmstead and part of a separate community located south of the bend in the Red River (Figure 1). In terms of a supporting mound center, the Battle Mound site is located approximately $20 \mathrm{~km}$ down river by way of the current channel and is a large mound site. Recent research at Battle Mound demonstrates the mound was in use during the Haley and Belcher periods (McKinnon 2013). There is also the Crenshaw site with its multiple mounds located approximately 15 $\mathrm{km}$ upriver and on the opposite side of the river from the Red Cox site. Recent radiocarbon dates from Crenshaw reveal Haley and earlier phase occupations (Schambach 2014). While the relationship of the Red Cox site to these two mound sites (and the extent of the community in this area) is not fully realized, the dispersed settlement patterning and the data we have demonstrates that the Red Cox site is characteristic of a typical Caddo farmstead and one of many that would have been distributed on the landscape during Haley and Belcher phase times.

\section{The Red Cox Site}

The Red Cox site is located in what is today Lafayette County, Arkansas and is named after Mr. and Mrs. Red Cox - tenant occupants when the site was originally recorded. Like many sites in the Great Bend region, the site was situated along a natural sandy ridge. At present, what remains of the site (if anything) is located about

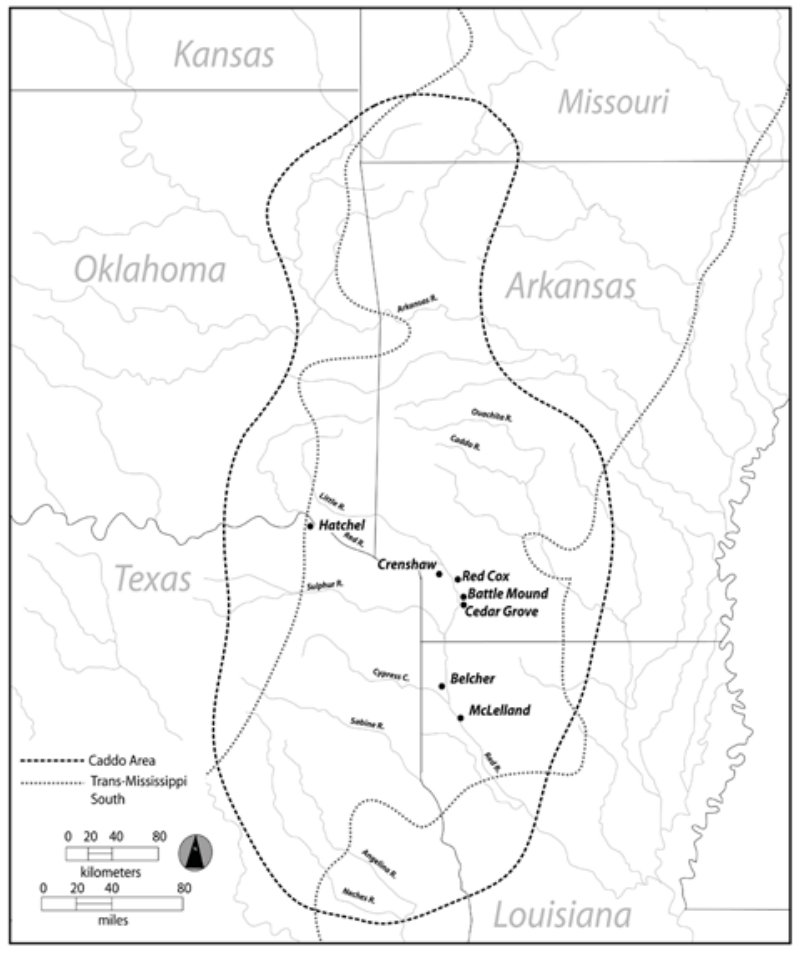

Figure 1. Location of sites discussed in text.

$2 \mathrm{~km}$ east of the current channel of the Red River. The Mays Lake oxbow is about $0.75 \mathrm{~km}$ from the site and may represent an active channel during occupation. Long time avocationalists and Arkansas Archeological Society (ARAS) members of the area, Mr. Hershel Kitchens and his wife Mrs. Dot Kitchens, first recorded the site in 1968 after a polished celt, flint knife, and a "scattering of Caddo pottery" were collected from the surface (Figure 2). A midden area is also mentioned in the notes, but the exact location is not documented in the site files (Arkansas Archeological Survey [ARAS] Site File [SF] 3LA18).

On April 9, 1975, Hershel Kitchens alerted Dr. Schambach, Southern Arkansas University (SAU) station archaeologist at the Arkansas Archeological Survey (ARAS) at the time, of land-leveling activities at the site. Realizing there was little time to conduct a formal excavation, Schambach and Dot and Hershel Kitchens salvaged an "enormous sample of carbonized corn and acorns, several partial vessels and lots of sherds" from the remains of the floor of a collapsed burned structure in the short time between four in the afternoon and nightfall around 8:30pm (ARAS SF 3LA18). The structure was a "house that burned intact sometime in the fall or winter with everything in it" (ARAS SF 3LA18). At nightfall, land-levelers informed Schambach "it wasn't at all likely they would hit that spot [where the Caddo house as located] within the next 


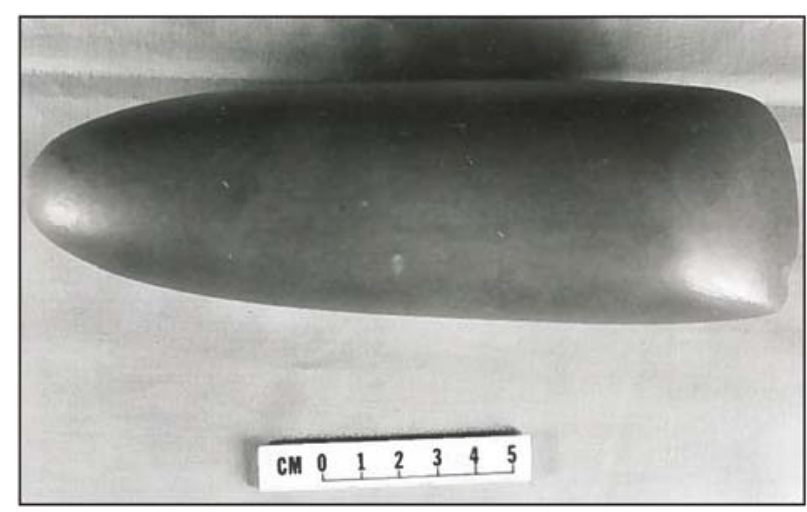

Figure 2. Celt collected from the Red Cox site in 1968 (ARAS 793399).

two days" (ARAS SF 3LA18). Upon returning to the site the next day with additional society member volunteers and Dr. Ann Early, Henderson State University (HSU) station archaeologist from Arkadelphia "who had dropped everything to come over", it was discovered that the "dirt buggies [were] running directly over [the site] and nowhere else" (ARAS SF 3LA18). The landscape had been completely leveled by workers who thought the site might contain "buried treasure... even though we'd explained carefully the night before what we were doing" (ARAS SF 3LA18). After the machines stopped for the day, Schambach and his crew surveyed and tested the remainder of the site for any additional structures, churned up artifacts, and possible disturbed burials to no avail.

While only a portion of the site and structure were salvaged, the efforts were productive as it led to an important, although small, collection of archeological material from the floor of a burned Caddo farmstead structure. Items salvaged include several ceramic sherds, large fragments from at least three broken and incomplete vessels, a significant amount of carbonized corn kernels and cobs (Zea mays), charred acorn nutmeat and nutshells (Quercus sp.), burned wood fragments, bits of daub, and a few lithic debris. A single radiocarbon date from wood charcoal was acquired shortly after the salvage (ARAS SF 3LA18) and a second date from charred remains was recently obtained (McKinnon 2014).

\section{Analysis of Material Remains}

The salvaged material collected from the structure floor consists of 84 ceramic sherds $(>1 \mathrm{~cm}$ in diameter), three broken and partially complete vessels ( 95 sherds), 1,912 small pieces of daub ( $395.10 \mathrm{~g}$; $0.87 \mathrm{lbs})$, six lithic fragments (12.90 g; $0.03 \mathrm{lbs})$, two broken manos $(162.30 \mathrm{~g}$; $0.36 \mathrm{lbs})$, and $13.637 \mathrm{~kg}(30.06 \mathrm{lbs})$ of soil to be floated. A small number of artifacts are noted as "not necessarily part of the house floor" and consist of two historic cow bone fragments $(23.90 \mathrm{~g} ; 0.052$ lbs), eight small lithic pieces (48.80 g; $0.107 \mathrm{lbs})$, and a single historic whiteware sherd. Interestingly, apart from the two historic cow fragments, there were no faunal remains in the Red Cox material. While meat protein would have been a desired food source, large numbers of animals could have been less frequent or unavailable and flora more available seasonally (Early 2013:6). Nonetheless, the absence of any faunal remains suggests processing and cooking was perhaps conducted at outside cooking areas not identified in the salvage collection (see McKinnon 2013).

This paper focuses on the material collected from the structure floor with an emphasis on the botanical remains and ceramic material. A short discussion on collected daub and two mano fragments is included. The two acquired radiocarbon dates are also discussed below.

\section{Botanical Remains}

Before analysis of the material could begin, the salvaged soil containing the floral material (now hardened after 40 years in the box) was floated. Each of the six flat boxes contained four sub-sections that were photographed and weighed on a standard triple-beam balance scale (Figure 3). Material was floated using a simple manual bucket flotation method in the anthropology laboratory at UCA (see Pearsall 2015). Soil from each of the subsections was submerged into a 5-gallon bucket and filled two-thirds full of water. To break apart the hard soil clods, the water was stirred by hand. Larger pieces were gently maneuvered to break the soil apart so that stirring would free the corn, nuts, and wood fragments. A few ceramic sherds were found within the soil clods and are included in the sherd analysis.

Once the soil was adequately broken up and botanical remains separated, light fractions were poured through a $0.25 \mathrm{~mm}$ (60 mesh) sieve. Each time the mesh became full, materials were removed and set to dry in the laboratory and flotation proceeded with a clean mesh. After each pour, water was added to the remaining material at the bottom of the bucket and again stirred by hand. Contents from each pour through the 60 mesh were laid out on a tray covered with paper towels. The stirring and pouring process was repeated for each sub-section from one to four times depending on the size of the soil sample and until all soil was dissolved. When no additional material (light fraction) came to the surface in the bucket, soil and remaining materials (heavy fraction) were also poured though the $0.25 \mathrm{~mm}$ mesh. The process resulted in light and heavy fractions 

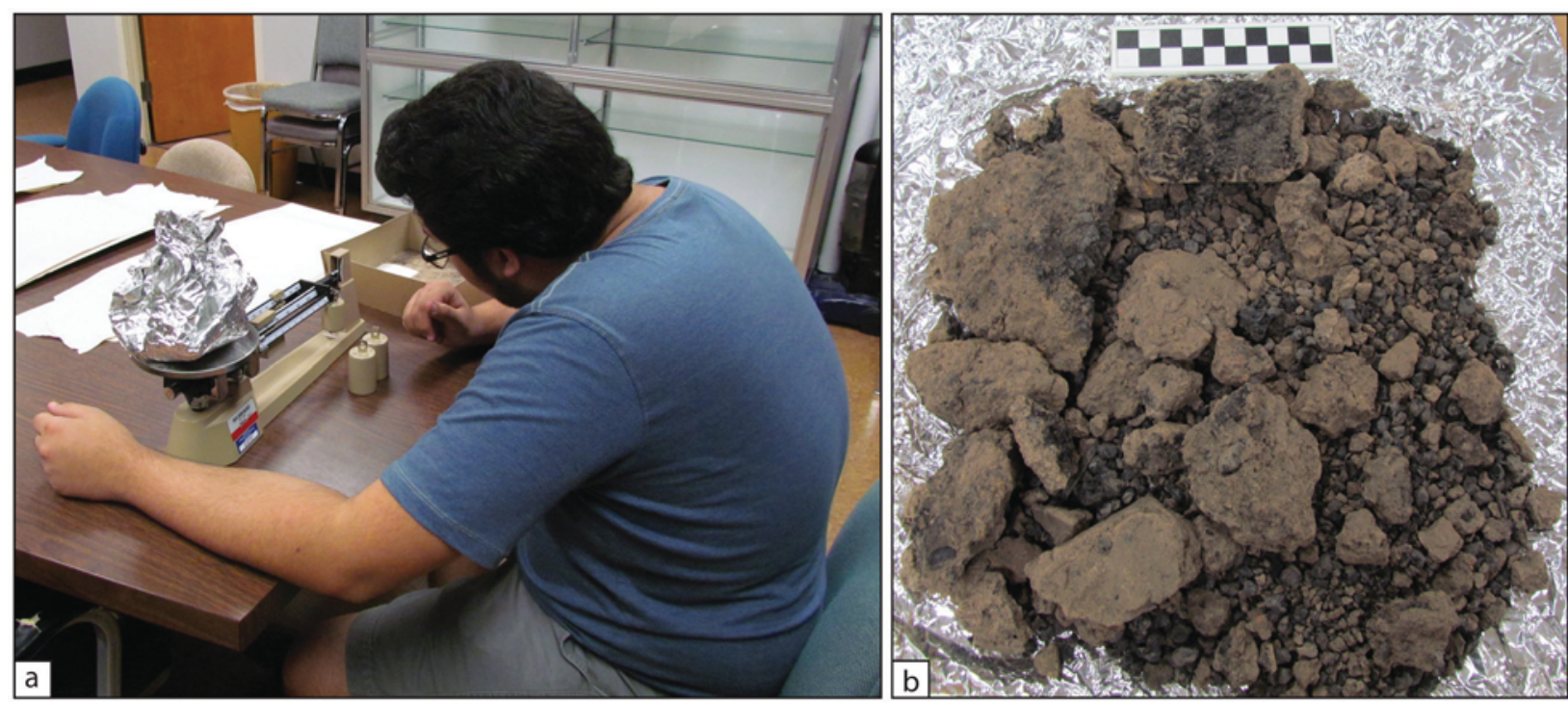

Figure 3. (a) Soil being weighed on a standard triple-beam balance and (b) one section of soil to be floated.

being combined in the laboratory, but light material that came to the surface quickly was protected from damage by heavier material by the frequent removal of light material from the mesh. Material was set to dry for a couple days and then dry sieved by hand (see Pearsall 2015). After drying, materials were size-sorted through a stack of graduated geologic mesh with square openings of $4.0 \mathrm{~mm}$ (5 mesh), $2.0 \mathrm{~mm}$ (10 mesh), and $0.5 \mathrm{~mm}$ (35 mesh). Results from the dry sieve sorting were bagged according to mesh size. Sorted corn kernels and cobs from the $4.0 \mathrm{~mm}$ sieve were analyzed in the UCA laboratory. Materials other than corn in the largest size fraction and all material that passed through the 4.0 $\mathrm{mm}$ square mesh (inadvertently including some corn fragments) were sent to Macrobotanical Analysis for sorting and identification (Bush 2016).

The corn analyzed in the UCA laboratory was sorted, counted, weighed, and values recorded. Of the total number of kernels collected from the 4.0 mm sieve $(n=5,712)$, a five percent random sample $(n=285)$ was analyzed using published guides on the measurement of maize kernels and cobs (Bird 1994; Whitehead 2004). While measurements were taken, it should be noted that the dimensions of kernels and cupules have become distorted as a result of charring, even at low temperatures, so the corn cannot be directly compared to modern or ancient, uncarbonized corn. Much archeological literature, however, compares carbonized to uncarbonized corn, so the measurements should be useful to other researchers (Goette et al. 1994:12-14). The analysis of the sample reveals a mean of $7.4 \mathrm{~mm}$ kernel height, $7.5 \mathrm{~mm}$ kernel width, and 4.1 mm kernel thickness, with a maximum height at 10.7 $\mathrm{mm}$, width $11.4 \mathrm{~mm}$, and thickness $7.0 \mathrm{~mm}$. Shapes are both round and square where 150 (53 percent) are classified as round in shape and 135 (47 percent) are classified as square. Differences in size and shape may relate to processing techniques (e.g., nixtamalization versus untreated corn) and they may correlate with different varieties of corn. Planting multiple varieties would represent a strategy related to reducing risk, since diversity of corn varieties would necessitate separate crops and differential exposure to flooding or rainfall which would impact yields (Dering 2004:332; Perttula 2008:96).

Several cob fragments were collected in 1973 and described by Schambach as "very large, the biggest I've seen from the area" (ARAS SF 3LA18). At the time of collection, Schambach measured a single cob at 140 $\mathrm{mm}$ in length. Today, most of the cobs have deteriorated and are in fragments. The largest fragment $(25.77 \mathrm{~mm})$ is a small-grained maize cob with an intact rachis and 10 -row cupule architecture. Kernel angle measurements (30-50 degrees) all fall within the range of 8-12 row corn. Cupule width ranges from $2.3 \mathrm{~mm}$ to $3.1 \mathrm{~mm}$.

At Macrobotanical Analysis, materials not analyzed at UCA were examined under a stereoscopic microscope at 7-45 X magnification, sorted, counted, weighed, recorded, and labeled. Weights were taken on an Ohaus Scout II 200 x $0.01 \mathrm{~g}$ electronic balance. In addition, a sample of twenty randomly-selected wood charcoal specimens was identified from the $4.0 \mathrm{~mm}$ size fraction. Wood charcoal fragments selected for identification were snapped to reveal a transverse section and examined under a stereoscopic microscope at 28180 X magnification. When necessary, tangential or radial sections were examined for ray seriation, presence 


\begin{tabular}{|c|c|c|c|c|c|c|}
\hline Accession \# & Type & Botanical Name & Common Name & NISP* & Weight (g) & Comments \\
\hline $75-87-1-1 \cdot 3$ & Nutmeat & Quercus sp. & Acorn & 380 & 37.59 & single cotyledons, whole nuts, fragments \\
\hline $75-87-1-1-3$ & Nutshell & Quercus sp. & Acorn & 33 & 0.54 & \\
\hline $75-87-1 \cdot 1-3$ & Cupule (cap) & Quercus sp. & Acorn & 1 & 0.03 & fragment \\
\hline $75-87-1-1 \cdot 3$ & Rachis (cob) & Zea mays & Corn & 3 & 0.03 & 1 whole cupule, 2 attached glumes \\
\hline $75-87-1-1-3$ & Seed & Zea mays & Corn & 46 & 2.06 & 6 whole \\
\hline $75-87-1 \cdot 1-3$ & Soil with stem impressions & & & 1 & 0.12 & \\
\hline $75-87-1 \cdot 1-4$ & Nutmeat & Quercus sp. & Acorn & 2 & 0.37 & loose cotyledons, nearly whole \\
\hline $75-87-1-1-5$ & Wood & Diospyros virginiana & Eastern persimmon & 19 & 47.87 & from same stem/limb, about 8 yrs' growth, diameter $\sim 37.5 \mathrm{~mm}$, outer rings present, bark absent \\
\hline $75-87-1-1-6$ & Wood & Morus rubra & Red mulberry & 8 & 1.03 & \\
\hline $75-87-1 \cdot 1-6$ & Wood & Salix sp. & Willow & 2 & 0.14 & \\
\hline $75-87-1-1-6$ & Wood & Froxinus sp. & Ash & 8 & 0.15 & \\
\hline $75-87-1-1-6$ & Wood & Quercus sp. & Oak & 1 & 0.31 & no tyloses but white group latewood, wide rays \\
\hline $75-87-1 \cdot 1-6$ & Wood & Hardwood & Hardwood & 1 & 0.02 & pith, 1st yr growth \\
\hline $75-87-1-1-6$ & Wood & Diospyros virginiana & Eastern persimmon & 1 & 0.11 & \\
\hline $75-87-1-1-6$ & Wood & Not examined & Not examined & 326 & 9.51 & \\
\hline $75-87-1 \cdot 1-6$ & Stem & Arundinaria sp. & Cane & 59 & 2.24 & split \\
\hline $75-87-1 \cdot 1-6$ & Seed & Zea mays & Corn & 8 & 0.12 & fragments \\
\hline $75-87-1-1-6$ & Nutmeat & Quercus sp. & Acorn & 2 & 0.07 & \\
\hline $75-87-1-1-6$ & Nutshell & Quercus sp. & Acorn & 5 & 0.08 & \\
\hline $75-87-1-1-6$ & Bark & & & 16 & 0.25 & \\
\hline $75-87-1-1-6$ & Soil with stem impressions & & & 5 & 0.32 & \\
\hline $75-87 \cdot 1 \cdot 1 \cdot 7$ & Examined residue $>2 \mathrm{~mm}$ & & & 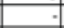 & 5.75 & 2 splits of $5.0 \mathrm{ml}$ each \\
\hline $75-87-1-1-8.1$ & Examined residue $>1 \mathrm{~mm}$ & & & - & 6.76 & 2 splits of $5.0 \mathrm{ml}$ each \\
\hline $75-87-1-1-8.2$ & Examined residue $>0.5 \mathrm{~mm}$ & & & - & 6.67 & 2 splits of $5.0 \mathrm{ml}$ each \\
\hline $75-87-1-1-9$ & Examined residue from bottom pan $(<0.5 \mathrm{~mm})$ & & & 9 & 5.7 & 2 splits of $5.0 \mathrm{ml}$ each \\
\hline
\end{tabular}

Table 1. Recovered botanical remains from the Red Cox site.

of spiral thickenings, types and sizes of intervessel pitting, and other minute characteristics that can only be seen at the higher magnifications of this range.

Due to constraints of time and budget, only a portion of material that fell through the $4.0 \mathrm{~mm}$ mesh ("residue") was examined. Using a method from population ecology designed to maximize the number of taxa identified for the amount of material examined ("species area curve"), random splits of $5.0 \mathrm{ml}$ from each size fraction were examined under a stereoscopic microscope at 7-45 X magnification for types of botanical remains that had not been previously identified until two successive splits failed to produce new taxa (Adams 2004). Splits were taken from the $2.0 \mathrm{~mm}, 1.0$ $\mathrm{mm}, 0.5 \mathrm{~mm}$, and bottom pan size fractions.

Botanical materials were identified to the lowest possible taxonomic level by comparison to materials in the Macrobotanical Analysis comparative collection and through the use of standard reference works (Core et al. 1979; Davis 1993; Hoadley 1990; InsideWood 2004; Martin and Barkley 2000; Panshin and de Zeeuw 1980; Wheeler 2011). Botanical nomenclature follows that of the PLANTS Database (USDA, NRCS 2016). A variety of plants were identified in the Red Cox material (Table 1) with several economic categories interpreted (Table 2).

Not all plant material is completely carbonized. It is very dark brown rather than black. However, the material is interpreted as archeological due to 1) the relatively recent age of the deposits, 2) the

\begin{tabular}{|l|l|}
\hline \multicolumn{1}{|c|}{ Economic Category } & \multicolumn{1}{c|}{ Plant Type } \\
\hline Food plants & Corn kernels, acorn nutmeats \\
\hline Food-related debris & Corn cob parts, acorn nutshells and caps \\
\hline Fiber plant debris & Split cane \\
\hline Fuel wood and associated bark & Mulberry, ash, willow, oak, persimmon, bark \\
\hline Structural or craft wood & Persimmon \\
\hline
\end{tabular}

Table 2. Plant remains from the Red Cox Site, by category. absence of uncarbonized (modern contaminant) plant material, and 3) the co-occurrence of fully carbonized and incompletely carbonized plant remains. Further, Schambach noted at the time of excavation that corn cobs were burned only on the outside, implying a zone of semi-carbonized material between the burned exteriors and rotted interiors. Materials consisted primarily of acorn parts and wood charcoal. Some split cane stems (Arundinaria sp.) were identified and measure approximately 1.0-5.0 mm wide, consistent with cane stems that have been vertically divided into four or eight splits (Figure 4). They range between 1.5 and $2.0 \mathrm{~mm}$ thick. The inner tissue has not been scraped away ("cleaned") for fine basketry. The specimens may represent half-processed cane stems intended for use in basketry, but they could also have been the large grass employed in building construction that left impressions on the daub fragments recovered (see below). A few small fragments of corn kernels and corn cob parts (cupules, glumes) in addition to those sorted and measured at UCA were also identified (Figure 5).

The acorn nutmeats consist of whole nutmeats (two attached cotyledons), single cotyledons, and fragments (Figure 6a). A fragment of an acorn cap and acorn nutshell fragments were also identified (Figure $6 b)$.

The wood charcoal in Accession \# 75-87-1-1-5 (see Table 1) is interpreted as a single stick or pole, as all fragments in the accession are complete or nearly complete stems of the same species (eastern persimmon, Diospyros virginiana) with approximately the same diameter (roughly $37.5 \mathrm{~mm}$ ) and the same number and size of eight growth rings (Figure 7). Although the outer rings are present on most fragments, the bark has either fallen off or, more likely, been removed. Persimmon is a member of the ebony botanical family (Ebenaceae), and its heartwood is dark brown to black. The wood is very 

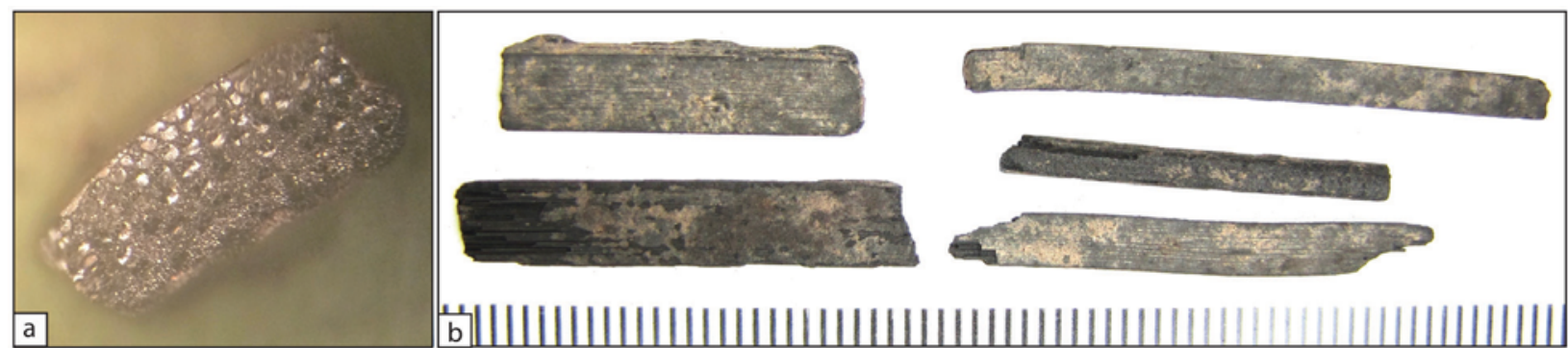

Figure 4. (a) Split cane stems (Arundinaria sp.), Accn \# 75-87-1-1-6-9. Scale in mm and (b) Cross section of a split cane stem (Arundinaria sp.), Accn \# 75-87-1-1-6-9.
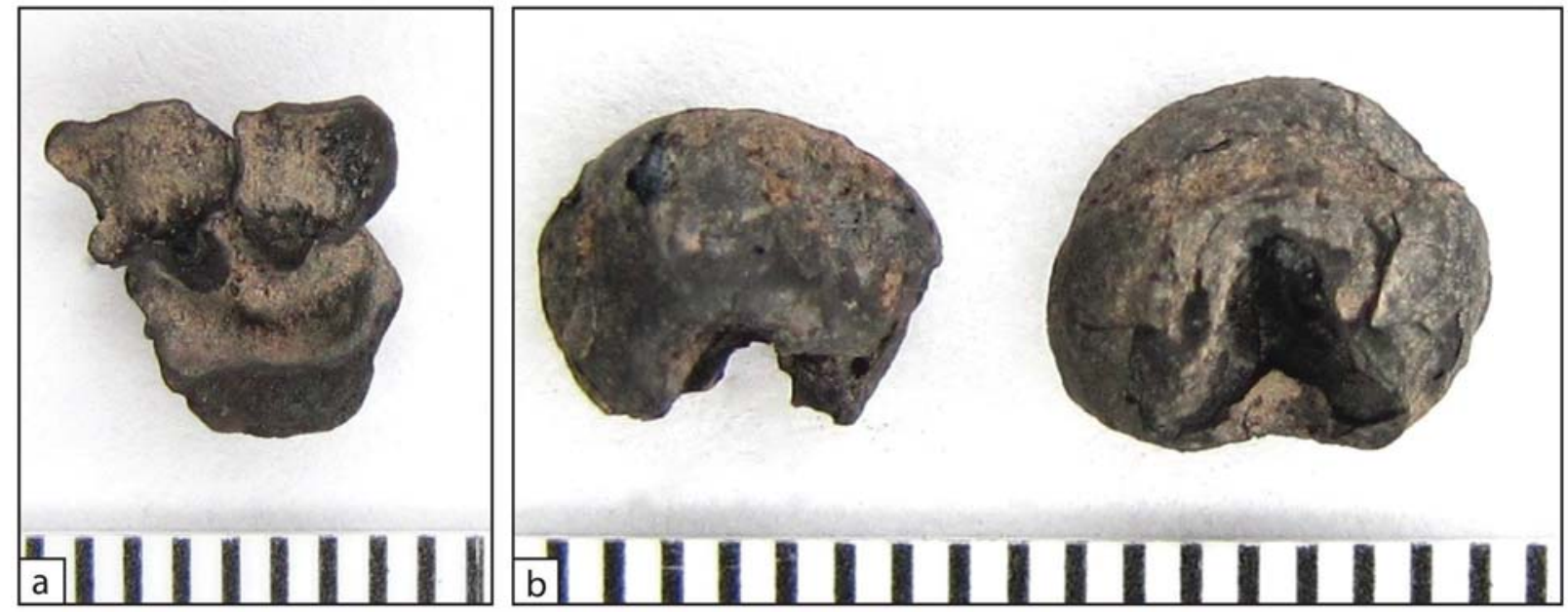

Figure 5. (a) Corn cupule with two attached glumes (Zea mays). Accn \# 75-87-1-1-3-3. Scale in mm. (b) Corn kernels (Zea mays). Accn \# 75-87-1-1-3-5. Scale in mm.
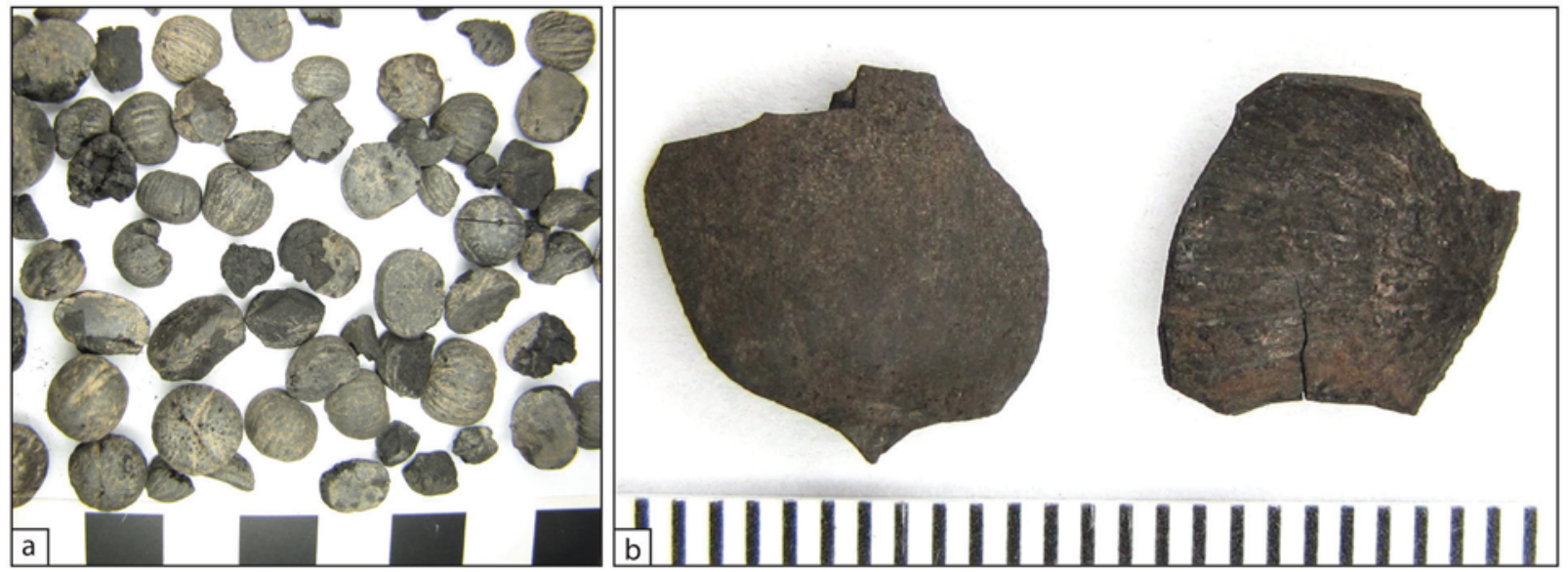

Figure 6. (a) Acorn nutmeats (Quercus sp.). Accn \# 75-87-1-1-3-1. Scale in $\mathrm{cm}$ and (b) Acorn nutshell (Quercus sp.). Accn \# 75-87-1-1-3-2. Scale in $\mathrm{mm}$.

tough, used for golf clubs in recent times, and suitable for digging sticks or tool handles in the past (Elias 1980; Little 1980). Other wood charcoal is interpreted as fuel wood and/or wood from diverse items and parts of the structure, since it consists of several species such as mulberry, ash, willow, oak and with no clear patterns in size or growth rings. Bark is also present. Mulberry, ash, and willow trees are often found growing along streams. Oaks and persimmons may grow along streams, but they also occur in upland situations. The variability of wood species from different habitats suggests a strategy focused on resource extraction from a wide range of local environments typical of the Red River floodplain. 


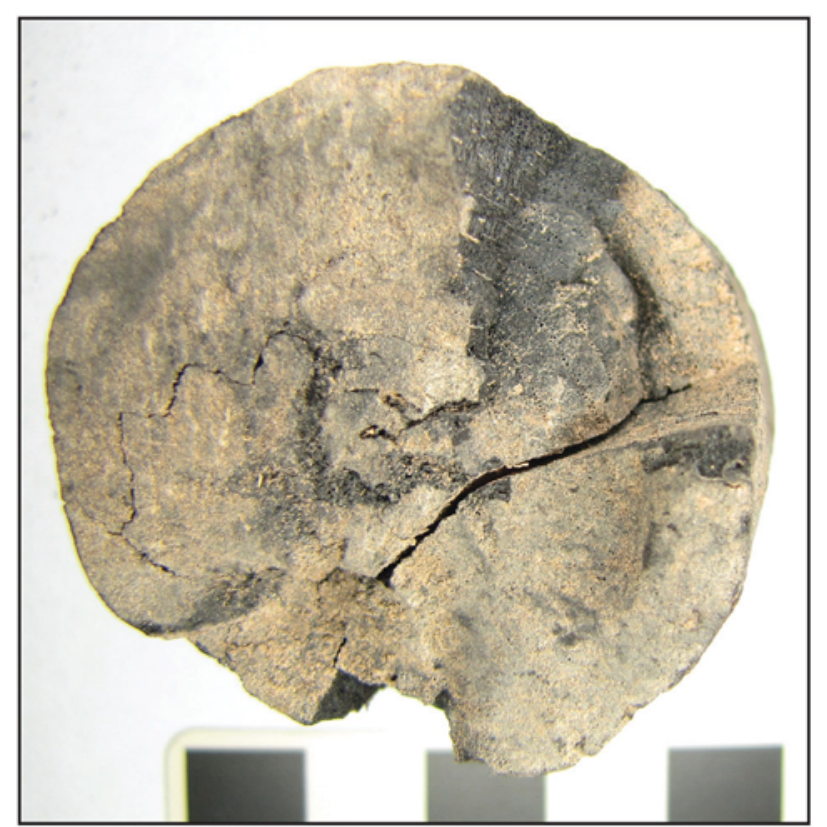

Figure 7. Transverse section of eastern persimmon wood (Diospyros virginiana). Accn \# 75-87-1-1-5. Scale in $\mathrm{cm}$.

\section{Ceramic Material}

Ceramics collected from the structure floor were analyzed in the UCA anthropology laboratory. Ceramic sherds were sorted by type of design and temper present using a tabletop grid system for easy sorting. Where visible, the observable design on each sherd was noted and temper was recorded. To sort by temper, a small corner of each sherd was broken to get a fresh view of the ceramic temper. Each sherd was examined under an AmScope binocular 10-60 X microscope at either $10 \mathrm{X}$ or $30 \mathrm{X}$ magnification to determine temper present. Temper present includes bone, grog, clay, and shell (which is mostly leached but easily identifiable based on linear voids) and contains numerous inclusions that are difficult to identify without conducting a thin-section petrographic analysis. There were a variety of designs on sherds that are identified as plain, brushed (grassy stems taken across the vessel in a horizontal direction), incised (markings made while the clay was full or partially wet), engraved (markings made when the vessel had dried), punctated (impressions made by a stick or thumb nail), or a combination of brushed-incised, incised-brushed, and punctated-incised (Table 3).

A few designs have been assigned to several possible ceramic types (Figure 8). Six sherds are typed as Belcher Engraved. Four are typed as likely Foster Trailed-Incised. There is a single possible Glassell Engraved sherd, a single possible Hempstead Engraved, a single possible Hodges Engraved, and five possible Pease Brushed Incised or Karnack Brushed-Incised sherds. Hempstead and Pease Brushed are often associated with Haley Phase times whereas Belcher, Foster-Trailed, Glassell, Karnack, and Hodges are often associated with Belcher Phase times (see Kelley 2012; Webb 1959). Certainly, the structure was not standing for longer than perhaps 20-25 years (see Davy 1982; Good 1982) where the combination of both Haley and Belcher Phase vessels suggests a timeframe shortly after Haley phase and into the early part of the Belcher phase. Radiocarbon dates discussed below support this assumption.

Additionally, the remains of at least three broken ceramic vessels $(1,2, \& 3)$ from the house floor are also in the collection (Figure 9). Schambach's weekly report document there was a large pile of carbonized corn with a layer of acorns resting over the corn (ARAS SF 3LA18). Beneath the pile of corn and nuts were the remains of three crushed ceramic vessels that were resting on the house floor. The arrangement of corn and acorn resting on the crushed vessels suggests the vessels were used as storage containers for harvested corn and nut resources and that the structure had burned, perhaps in late fall or winter, with food contents still inside the vessels. Schambach's observations of the corn at the time of collection corroborate this suggestion where he states the abundance of loose kernels is because the material "had burned on the outside and then the cobs rotted away on the inside" (ARAS SF 3LA18). Vessel 1 is interpreted as a Belcher Ridged jar (see Suhm et al. 1954:246) with temper of crushed shell mixed with clay. Vessels 2 and 3 are bone temper and are not typed. Their shapes are undeterminable.

\begin{tabular}{|c|c|c|c|c|c|c|c|c|c|}
\hline & Brushed & Incised & Punctated & Engraved & Punctated/Incised & Brushed/Incised & Incised/Brushed & Plain & Totals \\
\hline Clay & 1 & 2 & & 5 & & & 1 & 31 & 40 \\
\hline Grog & 1 & 5 & 3 & & 1 & 1 & & 2 & 13 \\
\hline Bone & 46 & & & & & & & & 46 \\
\hline Shell & 3 & & & 7 & & 1 & & 2 & 13 \\
\hline Clay/Shell & & & & & & 49 & & & 49 \\
\hline Grog/Shell & 1 & 6 & & & & & & 7 & 14 \\
\hline Bone/Grog & 1 & & & & & & & 3 & 4 \\
\hline Totals & 53 & 13 & 3 & 12 & 1 & 51 & 1 & 45 & \\
\hline
\end{tabular}

Table 3. Recovered ceramic remains from the Red Cox site. 


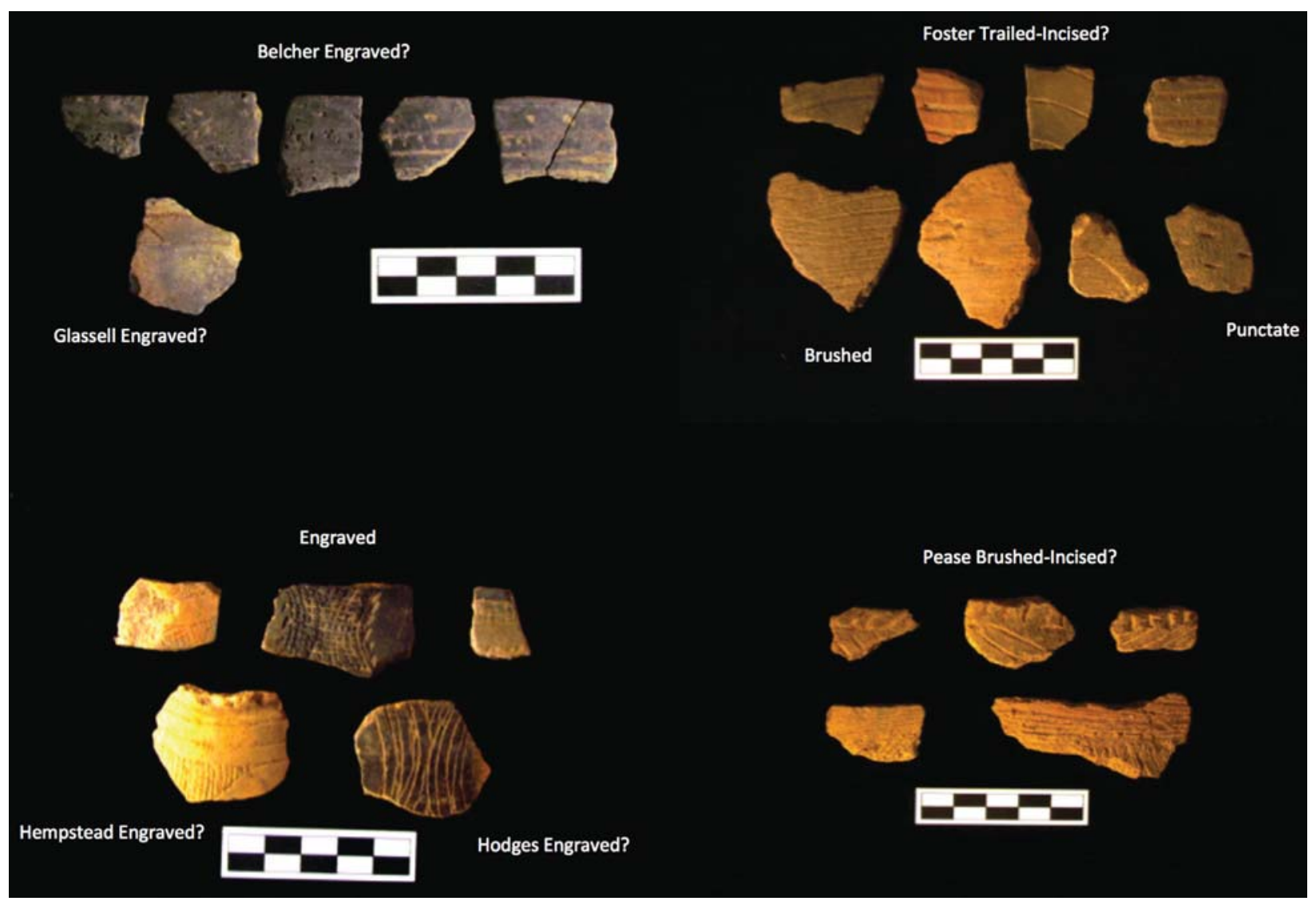

Figure 8. Typed sherds: top-left, Belcher Engraved and Glassell Engraved; top-right, Foster Trailed-Incised; bottomleft, Hempstead Engraved and Hodges Engraved; bottom-right, Pease Brushed Incised.

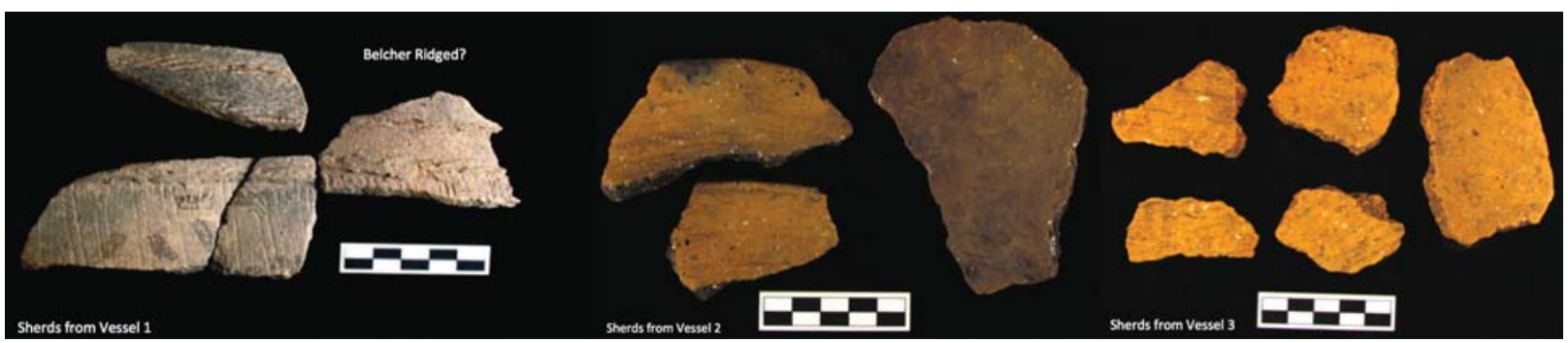

Figure 9. Select remains of broken vessels 1, 2, and 3. Vessel 1 is typed as a possible Belcher Ridged jar.

\section{Additional Remains}

Numerous pieces of daub were also collected from the structure floor and are variable in size and coloration. There are large pieces that were clearly subjected to intense heat based on vitrification and the associated orange color. However, the majority of daub was a darker grey color with impressions $1.98 \mathrm{~mm}-2.63$ $\mathrm{mm}$ in width of large-stemmed grass, such as cane Arundinaria sp.), switchgrass (Panicum virgatum), or big bluestem (Andropogon gerardii) (Figure 10). The difference in coloration is likely a result of exposure to different burning temperatures. Using the work of Stevanovic (1997:368) to correlate daub color with corresponding temperatures, the orange color daub (7.5YR 5/8) is a result of burning temperatures around 600 degrees Celsius whereas the darker grey color daub (10YR 3/2) is the result of a lower burning temperature at 400 degrees Celsius. The presence of large-stemmed grass impressions also suggests that these fragments are the remains of clay that was packed into the walls. Perhaps the darker colored daub lined the interior walls of the structure and thus was more insulated from direct heat during the burning of the structure. If this was the case where differential daub color represents exposure to various burning temperatures, it suggests the house burned very rapidly and was then left to smolder as it cooled. The rapid burning of a grass lodge structure has 


\begin{tabular}{|c|c|c|c|c|c|}
\hline $\begin{array}{l}\text { Sample ID and } \\
\text { Provenience }\end{array}$ & $\begin{array}{l}\text { Measured } \\
\text { Radiocarbon } \\
\text { Age Before } \\
\text { Present }\end{array}$ & $\begin{array}{l}13 \mathrm{C} / 12 \mathrm{C} \\
\text { Ratio }\end{array}$ & \begin{tabular}{|l|} 
Conventional \\
Radiocarbon \\
Age Before \\
Present
\end{tabular} & $\begin{array}{l}\text { Calibrated Age } 1 \text { sigma range } \\
\text { (68\% probability) }\end{array}$ & $\begin{array}{l}\text { Calibrated Age 2-sigma range } \\
\text { (95\% probability) }\end{array}$ \\
\hline $\begin{array}{l}\text { Krueger GX-6745, } \\
75-87 \text {, wood } \\
\text { charcoal. }\end{array}$ & $290+/-115 \mathrm{BP}$ & & & $\begin{array}{l}\text { Cal AD } 1453-1676 \text { and } \\
\text { Cal AD } 1768-1771 \text { and } \\
\text { Cal AD } 1777-1799 \text { and } \\
\text { Cal AD } 1941-1951\end{array}$ & $\begin{array}{l}\text { Cal AD } 1433-1708 \text { and } \\
\text { Cal AD } 1718-1827 \text { and } \\
\text { Cal AD } 1831-1889 \text { and } \\
\text { Cal AD } 1910-1953\end{array}$ \\
\hline $\begin{array}{l}\text { Beta } 382662,75- \\
87-1-1-2, \text { chared } \\
\text { material. }\end{array}$ & $370+/-30$ BP & -25.7 o/oo & $360+/-30 \mathrm{BP}$ & $\begin{array}{l}\text { Cal AD } 1465-1520 \text { and } \\
\text { Cal AD } 1575-1630\end{array}$ & Cal AD 1450 - 1640 \\
\hline
\end{tabular}

Table 4. Radiocarbon results from the Red Cox site.

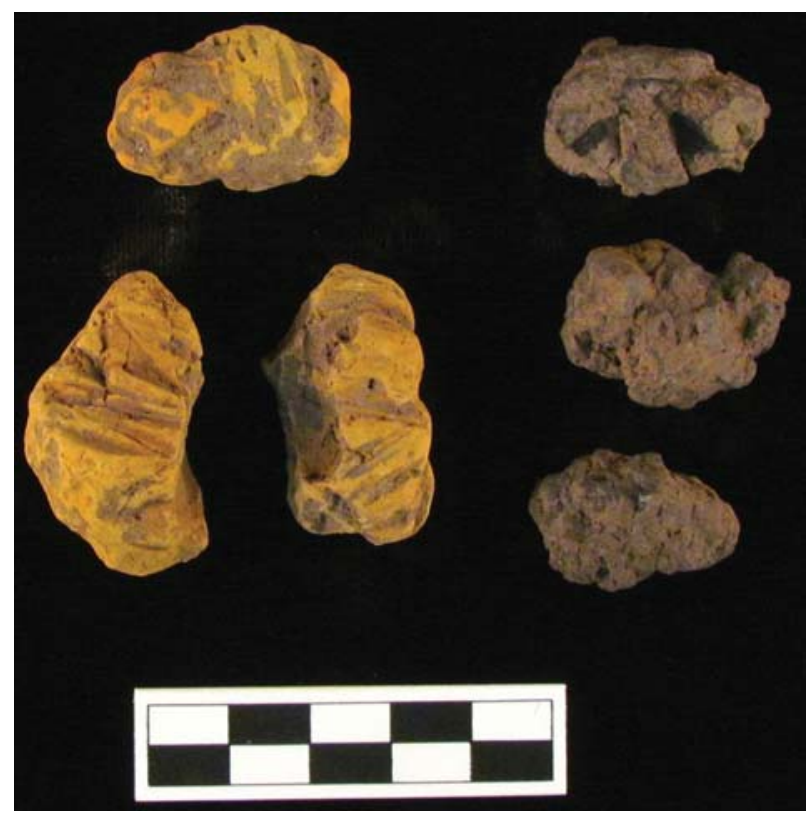

Figure 10. Daub from the Red Cox site.

been documented with the modern construction and subsequent burning at the George C. Davis (41CE19) site in east Texas. In that experiment, a grass lodge was constructed to better understand construction methods (Cheatham 1992; Perttula and Skiles 2014). After several years, the structure was set aflame and within minutes had fully collapsed and the fire diminished. Archeologically, the identification of burned farmstead structures at sites along the Red River is not common. For example, at Cedar Grove, McLelland, and Joe Clark excavated houses had not been burned (Kelley 2012; Trubowitz 1984). The lack of burned farmstead structures suggests the process of disposal or termination of farmstead structures is different than that reserved for mound structures, where structures were cleaned, burned, and then covered with a layer of soil (see Trubittt 2009; Schambach 2009; Webb 1959; Wood
1963). Since several vessels containing food remains were found within the structure at Red Cox, perhaps the burned structure was the result of unrelated events, such as lightning or a naturally occurring fire.

Lithic material is composed of a handful of debitage from locally sourced material and two broken manos. The association of manos on the house floor offers visibility into the potential nature of domestic activities that occurred within the structure. From the vast amount of acorn nuts $(n=421)$ and over 5,000 kernels of maize, it is certainly possible that these manos were used as the actual grinders for food processing occurring within the structure (see also Swanton 1942:133). That they were found within the structure and on the floor might also corroborate the idea the house burned in the late fall or winter when grinding food outside might have been a chilly endeavor.

\section{Radiocarbon Results}

Two radiocarbon dates have been acquired from charred material (Table 4). A single date was obtained from wood charcoal and a second from charred remains. Dr. Schambach submitted the first radiocarbon date from wood charcoal in 1979 to Geochron Laboratories (GX6745 ) where the results calibrate to a date range of A.D. 1430 - 1950 with a median probability of A.D. 1625 (Perttula et al. 2011:Table 2; Schambach 1982:9; AAS SF 3LA18). A recent accelerator mass spectrometry (AMS) date was acquired in 2014 from charred remains (McKinnon 2014). Advantages of AMS dating over standard radiocarbon or $\mathrm{C}-14$ dating are the small sample size (0.05 grams with AMS instead of 20 grams with C-14) and that dates returned typically contain lower statistical error ranges allowing for "tighter" dates along the calibration curve. The sample was sent to the Beta Analytic, Inc. radiocarbon laboratory in Miami, Florida. The date returned is $360+/-30$ B.P., which calibrates to A.D. 1450 - 1640 at 2-sigma (Beta 382662, 


\begin{tabular}{|c|c|c|c|c|c|}
\hline & Red Cox & Spirit Lake & Cedar Grove & McLelland & Joe Clark \\
\hline \multicolumn{6}{|l|}{ Wood } \\
\hline Elm (Ulmus sp.) & & $\mathrm{x}$ & $\mathrm{x}$ & & \\
\hline Oak (Quercus sp.) & $\mathrm{x}$ & $\mathrm{x}$ & $\mathrm{x}$ & & \\
\hline Eastern Persimmon (Diospyros virginiana) & $\mathrm{x}$ & & & & \\
\hline Red Mulberry (Morus rubra) & $\mathrm{x}$ & & & & \\
\hline Willow (Salix sp.) & $\mathrm{x}$ & & & & \\
\hline Ash (Fraxinus sp.) & $\mathrm{x}$ & & $\mathrm{x}$ & & \\
\hline Pine (Pinus sp.) & & $\mathrm{x}$ & $\mathrm{x}$ & & \\
\hline Hickory/Pecan (Carya sp.) & & & $\mathrm{x}$ & & \\
\hline Black Walnut (Juglans sp.) & & & $\mathrm{x}$ & & \\
\hline Cypress (Taxodium sp.) & & & $\mathrm{x}$ & & \\
\hline Maple (Acer sp.) & & & $\mathrm{x}$ & & \\
\hline Sycamore (Plantanus sp.) & & & $x$ & & \\
\hline \multicolumn{6}{|l|}{ Nut } \\
\hline Acorn Nut (Quercus sp.) & $\mathrm{x}$ & & $\mathrm{x}$ & $\mathrm{x}$ & $\mathrm{x}$ \\
\hline Beech Nut (Fagus grandifolia) & & & $\mathrm{x}$ & & \\
\hline Black Walnut (Juglans nigra) & & & $\mathrm{x}$ & & \\
\hline Hickory/Pecan Nut (Carya sp.) & & $\mathrm{x}$ & $\mathrm{x}$ & $\mathrm{x}$ & $\mathrm{x}$ \\
\hline Hazelnut (Corylus sp.) & & & $\mathrm{x}$ & & \\
\hline Pondnut (Nelumbo sp.) & & & & $\mathrm{x}$ & \\
\hline \multicolumn{6}{|l|}{ Cultigen } \\
\hline Corn (Zea Mays) & $\mathrm{x}$ & & $\mathrm{x}$ & $\mathrm{x}$ & \\
\hline Cucurbits (Lagenaria sp. \& C. pepo) & & & $\mathrm{x}$ & $\mathrm{x}$ & \\
\hline Bean (Phaselous sp.) & & & & $\mathrm{x}$ & $\mathrm{x}$ \\
\hline \multicolumn{6}{|l|}{ Grass } \\
\hline Cane (Arundinaria sp.) & $\mathrm{x}$ & & $\mathrm{x}$ & & \\
\hline
\end{tabular}

Seeds varieties were not recovered in the Red Cox material so they are not included here.

Table 5. Comparison of remains from select farmsteads.

sample 75-87) and in line with recovered sherds and proposed ceramic types during an early Belcher phase time.

\section{Comparative Discussions and Conclusions}

Although the Red Cox site was land-leveled and subsequently destroyed, the material salvaged by Dr. Schambach and his crew has proven to be very useful in placing the Red Cox site within the Caddo landscape. While the collection is incomplete and contains undeterminable sampling errors (given the salvage nature of the material), occurrences of botanical and ceramic material can be compared to select documented Red River farmsteads using a simple presence or absence analysis (Table 5).

\section{Botanical Comparisons}

The most prominent cultigen in the Red Cox material is corn, which is 89.2 percent of the collected botanical samples. Corn is also present at Cedar Grove and McLelland but in much smaller quantities. At Cedar Grove, corn occurs in 13.9 percent of the samples (King 1984:Table 14-1). At McLelland, corn occurs in 9 percent of the samples and only one percent at Joe Clark (Gardner 1997:114). Corn is not recorded at Spirit Lake, 
although the lack of corn is attributed to sampling error where only 1.5 cubic meters of the midden feature was excavated (Hemmings 1982:87). Certainly the family occupying the Red Cox site relied heavily on corn as a major source of subsistence, as has been documented ethnographically (Swanton 1942:127-131).

Acorn represents 6.25 percent of the collected botanical material from the Red Cox structure and is the only nutmeat present, perhaps because the meat of oily nuts like hickory and walnut tend to burn all the way to ash in fires. At Cedar Grove, McLelland, Joe Clark, and Spirit Lake, hickory nuts represent the most prominent nut present. The lack of hickory nuts at Red Cox could be related to sampling error, differential preservation, access to hickory stands, or a preference based on edible nutmeat (Note that Munson and colleagues include acorn nutmeats but not hickory or walnut nutmeats in their grouping of plants with middling archeological visibility [Munson et al. 1971:427]).

Although the sample is small, there is variability in wood types in the Red Cox collection. Oak (Quercus sp.) is recorded at Red Cox, Spirit Lake, and Cedar Grove. Ash (Fraxinus sp.) is recorded at Red Cox and Cedar Grove. Species such as eastern persimmon (Diospyros virginiana), red mulberry (Morus rubra), and willow (Salix sp.) are only recorded in the Red Cox material, although the lack of these at other sites could be related to small sampling size, such as at Spirit Lake. At the McLelland and Joe Clark sites, "no attempt was made to identify the taxa of either the wood or the stem fragments" (Gardner 1997:111), so there is nothing to compare with those samples.

Of particular interest are the Eastern

Persimmon pieces that are all from the same stem (see Table 1) and with the bark removed. The removal of bark suggests the hard, dense wood was reserved for architectural or tool use rather than as wood fuel. That there were no other stems or limbs recovered in the Red Cox material could indicate that the wood pieces were used for tool making, such as specialized digging sticks (Vines 1960).

\section{Ceramic Comparisons}

Many of the proposed types from the Red Cox material (Belcher Ridged, Foster Trailed-Incised, Glassell Engraved, Hodges Engraved, Hempstead Engraved, Karnack Brushed-Incised, Pease BrushedIncised) are present at Cedar Grove, McLelland, Joe Clark, and Spirit Lake sites and are representative of Haley and Belcher phase ceramic assemblages (Hoffman 1970; Kelley 2012).

In the Red Cox material, shell represents 31 percent of the temper present and 42 percent when sherds from the shell-tempered Vessel 1 are included in the calculation. A recent preliminary analysis of the Red Cox ceramic temper by Dr. Mary Beth Trubitt as part of a larger study to examine frequencies of shell-tempered pottery in the Caddo area reported, "39 percent [of the collection] tempered with a mixture of shell and grog" (Perttula et al. 2011:248). While the subjective concern of assigning temper using "megascopic" approaches rather than using thin-section petrography, and most recently digital image analysis (Livingood 2007; Reedy et al. 2014), has been discussed elsewhere (see Perttula et al. 2011:260; Stoltman 1989, 2001), the differences in percentages between the two are minimal and equally emphasize a large number of sherds containing shell temper. High occurrences of shell temper are also present at Cedar Grove where 85.95 percent of coarse ware and 9.91 percent of fine ware sherds had identifiable shell temper (Schambach and Miller 1984:109). At McLelland, 53.2 percent of the ceramics contained shell and only 22.5 percent at Joe Clark where 76.4 percent of the ceramics were grog tempered (Kelley 1997:38). At Spirit Lake, 42 percent of the sherds contained shell.

In the Red River Great Bend region, the presence and use of shell temper is a late introduction beginning in the Belcher phase and with more frequent occurrences in subsequent later phases (Perttula et al. 2011:246). Along with the acquired radiocarbon dates, the high percentage of shell temper at Red Cox (although not has frequent as at later sites, such as Cedar Grove, McLelland, and Joe Clark) also demonstrates that the site was occupied during early Belcher times. The fact that high occurrences of shell temper are present in the Red Cox ceramic sherds has cultural implications. Along with Caddo exploiting local food resources from the Red River floodplain and potential functional and societal benefits of using shell temper (see Perttula et al. 2011:260), the presence of shell temper potentially also hints at social boundaries between communities. Individuals within communities learned pottery-making techniques from one another and practiced social identification through their pottery styles and temper recipes (Early 2012; Girard et al. 2014:75-76).

In closing, the Red Cox site is an important example of a Middle-Late Caddo farmstead in the Red River valley. Farmsteads in the region were distributed across the landscape, similar to the Upper Nasoni community recorded in the Domingo Terán de los Ríos map of 1691 where each farmstead is documented as having at least one circular thatched-covered dwelling and associated structures (Swanton 1942:Plate 1). At Red Cox, material was salvaged from a residential structure, although any associated outbuildings or other 
structures were not identified or previously destroyed by land leveling. While distributed spatially, the family or families that called the Red Cox site their home were socially integrated into a larger community through a shared identity in subsistence strategies, ceramic design and production, and architectural techniques. With this analysis of the Red Cox material we can now situate the Red Cox site within the Red River landscape during a period shortly after Haley phase and into the early part of the Belcher phase and can use these data for continued comparisons of Caddo lifeways beyond those sites containing monumental earthen architecture.

\section{Acknowledgements}

Thanks to the Arkansas Archeological Survey for the opportunity to analyze the Red Cox material and to Dr. Schambach and team for salvaging the material that would be lost otherwise. The Arkansas Archeological Society Research Fund provided funding for the most recent AMS date. An earlier version of this paper was presented at the 2016 58th Caddo Conference and 23rd Annual East Texas Archeological Conference in Nacogdoches, Texas.

\section{References Cited}

Adams, Karen R.

2004 Archaeobotanical Analysis: Principles and Methods. Crow Canyon Archaeological Center. https://www.crowcanyon.org/ResearchReports/ Archaeobotanical/Principles_and_Methods/ principles_methods.asp Accessed 7/26/16.

Bird, Robert McK.

1994 Manual for the Measurement of Maize Cobs. In Corn and Culture in the Prehistoric New World, edited by Sissel Johannessen and Christine A. Hastorf, pp. 5-22. Westview Press.

Buchner, C. Andrew, Karla Oesch, Neal H. Lopinot, Gina S. Powell, Chester Walker, P., J. Rocco de Gregory, Nicholas P. Herrmann, and Susan L. Scott 2012 Archaeological Data Recovery at Foster Place (3LA27) and Site 3LA290 for the Red River Levee Rehabilitation Project (Item 9A-2), Lafayette County, Arkansas. PCI Report 31053. Panamerican Consultants, Inc., Memphis, Tennessee.

Bush, Leslie L.

2016 Plant Remains from a Feature at the Red Cox Site 3LA18, Lafayette County, Arkansas. Macrobotanical Analysis, Manchaca Texas.
Cheatham, Scooter

1992 The Caddo House Reconstruction. Bulletin of Primitive Technology 1(3):22-24.

Core, H. A., W. A. Cote and A. C. Day

1979 Wood Structure and Identification. 2nd ed. Syracuse University Press, Syracuse, New York.

Davis, Linda W.

1993 Weed Seeds of the Great Plains: A Handbook for Identification. University Press of Kansas, Lawrence.

Davy, Douglas M.

1982 Proximity and Human Behavior: Settlement Locational Pattern Change in Prehistoric Illinois. Ph.D. dissertation, Department of Anthropology, Southern Illinois University, Carbondale, Illinois.

Dering, J. Phil

2004 Archeobotanical Evidence for Agriculture and Wild Plant Use at 41RK214. In The Oak Hill Village (41RK214), Rusk County, Texas, by Robert Rogers and Timothy K. Perttula, pp. 329-336. Document No. 030083, PBS\&J, Austin, Texas.

Elias, Thomas S.

1980 The Complete Trees of North America: Field Guide and Natural History. Outdoor Life/Nature Books. Van Nostrand Reinhold Company, New York.

Fowler, Melvin L.

1997 The Cahokia Atlas: A Historical Atlas of Cahokia Archaeology, Revised Edition. University of Illinois at Urbana-Champaign Studies in Archaeology Number 2. Illinois Transportation Archaeological Research Program, Urbana, Illinois.

Gardner, Paul S

1997 Plant Remains. In Two Caddoan Farmsteads in the Red River Valley. edited by David B. Kelley, pp. 109-120. Arkansas Archeological Survey Research Series No. 51. Fayetteville, Arkansas.

Goette, Susan, Michele Williams, Sissel Johannessen, and Christine A. Hastorf

1994 Toward Reconstructing Ancient Maize: Experiments in Processing and Charring. Journal of Ethnobiology 14(1):1-21. 
Good, Carolyn E.

1982 Analysis of Structure, Burials, and Other Cultural Features. In The Deshazo Site, Nacogdoches County, Texas, edited by Dee Ann Story, pp. 51-112. Texas Antiquities Permit Series 7. Texas Antiquity Committee, Texas Historical Commission, Austin.

Guccione, Margaret J.

1984 Variations of the Red River Channel in Southwest Arkansas. In Cedar Grove: An Interdisciplinary Investigation of a Late Caddo Farmstead in the Red River Valley, edited by Neal L. Trubowitz, pp. 17-25. Arkansas Archeological Survey Research Series No. 23, Fayetteville.

2008 Impact of the alluvial style on the geoarcheology of stream valleys. Geomorphology 101:378-401.

Girard, Jeffrey S., Timothy K. Perttula, and Mary Beth Trubitt

2014 Caddo Connections: Cultural Interactions within and Beyond the Caddo World. Rowman \& Littlefield.

Early, Ann E.

2012 Form and Structure in Prehistoric Caddo Pottery Design. In The Archaeology of the Caddo, edited by Timothy K. Perttula and Chester P. Walker, pp. 26-46. University of Nebraska Press, Lincoln.

2013 A Short History of Prehistoric Arkansas Cuisine. Arkansas: The Journal of Arkansas Foodways 3:68

Hemmings, E. Thomas

1982 Spirit Lake (3LA83): Test Excavations in a Late Caddo Site on the Red River. In Contributions to the Archeology of the Great Bend Region, edited by Frank F. Schambach and Frank Rackerby, pp. 55-89. Research Series No. 22. Arkansas Archeological Survey, Fayetteville, Arkansas.

Hoadley, R. Bruce

1990 Identifying Wood: Accurate Results with Simple Tools. The Taunton Press, Newtown, Connecticut.

Hoffman, Michael

1970 Archaeological and Historical Assessment of the Red River Basin in Arkansas. In Archeological and Historical Resources of the Red River Basin, edited by Hester A. Davis, pp. 137-194. Research Series No. 1. Arkansas Archeological Survey, Fayetteville.
InsideWood

2004onwards Published on the Internet. http:// insidewood.lib.ncsu.edu/search. Accessed 7/26/16.

Jackson, Edwin H., Susan L. Scott, and Frank F.

Schambach

2012 At the House of the Priest: Faunal Remains from the Crenshaw Site (3MI6), Southwest Arkansas. In The Archaeology of the Caddo, edited by Timothy K. Perttula and Chester P. Walker, pp. 47-85. University of Nebraska Press, Lincoln, Nebraska.

Kelley, David B. (editor)

1997 Two Caddoan Farmsteads in the Red River Valley. Arkansas Archeological Survey Research Series No. 51. Fayetteville, Arkansas.

Kelley, David B.

2012 The Belcher Phase: Sixteenth- and SeventeenthCentury Caddo Occupation of the Red River Valley in Northwest Louisiana and Southwest Arkansas. In The Archaeology of the Caddo, edited by Timothy K. Perttula and Chester P. Walker, pp. 411-430. University of Nebraska Press, Lincon, Nebraska.

King, Adam

2003 Etowah: The Political History of a Chiefdom Capital. University of Alabama Press, Tuscaloosa, Alabama.

King, Frances B.

1984 Plant Remains from the Cedar Grove (3LA97) and Sentell (3LA128) Sites. In Cedar Grove: An Interdisciplinary Investigation of a Late Caddo Farmstead in the Red River Valley, edited by Neal L. Trubowitz, pp. 207-210. Research Series No. 23. Arkansas Archeological Survey, Fayetteville, Arkansas.

Knight, Vernon James, Jr., and Vincas P. Steponaitis 1997 Archaeology of the Moundville Chiefdom. University of Alabama Press, Tuscaloosa, Alabama.

Little, Elbert L.

1980 The Audubon Society Field Guide to North American Trees: Eastern Region. Alfred A. Knopf, New York. 
Livingood, Patrick C.

2007 Using Computer-Assisted Petrographic Analysis to Investigate Plaquemine Ceramic Recipes. In Plaquemine Archaeology, edited by Mark A. Rees, and Patrick C. Livingood, pp. 108-126. The University of Alabama Press, Tuscaloosa.

Martin, Alexander C., and William D. Barkley

1961 Seed Identification Manual. University of California Press, Berkeley.

McKinnon, Duncan P.

2013 Battle Mound: Exploring Space, Place, and History of a Red River Caddo Community in Southwest Arkansas. PhD dissertation. Department of Anthropology. University of Arkansas, Fayetteville, Arkansas.

2014 A Salvage along the Red River: An ARF-Funded AMS Date from the Red Cox Site (3LA18). Field Notes: Newsletter of the Arkansas Archeological Society 381:3-4.

Munson, Patrick J., P. W Parmalee, and Richard A. Yarnell

1971 Subsistence Ecology of Scovill, a Terminal Middle Woodland Village. American Antiquity 36:410 431.

Panshin, A. J. and Carol de Zeeuw

1980 Textbook of Wood Technology: Structure,

Identification, Properties, and Uses of the Commercial Woods of the United States and Canada. Fourth ed. McGraw-Hill Book Company, New York.

Pearsall, Deborah M.

2015 Paleoethnobotany: A Handbook of Procedures. $3 r d$ edition. Left Coast Press, Walnut Creek, California.

Perttula, Timothy K.

2005 1938-1939 WPA Excavations at the Hatchel Site (41BW3) on the Red River in Bowie, County, Texas. Southeastern Archaeology 24:180-198.

2008 Caddo Agriculture on the Western Frontier of the Eastern Woodlands. Plains Anthropologist 53(205):79-105.
Perttula, Timothy K., and Bob D. Skiles

2014 The Construction and Eventual Burning of the Experimental Caddo House Structure at the George C. Davis Site (41CE19) in East Texas. Bulletin of the Texas Archeological Society 85:4959.

Perttula, Timothy K., James E. Bruseth, Nancy Adele Kenmotsu, and William A. Martin

1995 Archeological Testing at the Cabe Mounds (41BW14), Bowie County, Texas. Cultural Resource Management Report 8. Department of Antiquities Protection, Texas Historical Commission, Austin, Texas.

Perttula, Timothy K., Mary Beth Trubitt, and Jeffrey S. Girard

2011 The Use of Shell-Tempered Pottery in the Southeastern United States. Southeastern Archaeology 30(2): 242-267.

Reedy, Chandra L., Jenifer Anderson, Terry J. Reedy, and Yimeng Liu

2014 Image Analysis in Quantitative Particle Studies of Archaeological Ceramic Thin Sections. Approaches in Archaeological Practice 2(4):252268.

Schambach, Frank F.

1982 The Archeology of the Great Bend Region in Arkansas. In Contributions to the Archeology of the Great Bend Region, edited by Frank F. Schambach and Frank Rackerby, pp. 1-11. Research Series No. 22. Arkansas Archeological Survey, Fayetteville, Arkansas.

1996 Mounds, Embankments, and Ceremonialism in the Trans-Mississippi South. In Mounds, Embankments, and Ceremonialism in the Midsouth, edited by Robert C. Mainfort and Richard Walling, pp. 36-43. Research Series No. 46. Arkansas Archeological Survey, Fayetteville, Arkansas.

2014 Introduction to the Crenshaw Bioanthropological Project. The Arkansas Archeologist 52:1-17.

Schambach, F.F., and John E. Miller, III

1984 A Description and Analysis of the Ceramics. In Cedar Grove: An Interdisciplinary Investigation of a Late Caddo Farmstead in the Red River Valley, edited by Neal L. Trubowitz, pp. 109-170. Research Series No. 23. Arkansas Archeological Survey, Fayetteville. 
Stevanovic, Mirjana

1997 The Age of Clay: The Social Dynamics of House Destruction. Journal of Anthropological Archaeology 16(4):334-395.

Stoltman, James B.

1989 A Quantitative Approach to the Petrographic Analysis of Ceramic Thin Sections. American Antiquity 54:147-160.

2001 The Role of Petrography in the Study of Archaeological Ceramics. In Earth Sciences and Archaeology, edited by Paul Goldberg, Vance T. Holliday, and C. Reid Ferring, pp. 297-326. Kluwer/Plenum, New York.

Swanton, John R.

1942 Source Material on the History and Ethnology of the Caddo Indians. Bulletin 132. Bureau of American Ethnology, Smithsonian Institution, Washington D.C.

Suhm, Dee Ann, Alex D. Krieger, and Edward B. Jelks 1954 An Introductory Handbook of Texas Archaeology. Bulletin of the Texas Archeological and Paleontological Society 25:144-227.

Trubitt, Mary Beth

2009 Burning and Burying Buildings: Exploring Variation in Caddo Architecture in Southwest Arkansas. Southeastern Archaeology 28(2):233247.

Trubowitz, Neal L. (editor)

1984 Cedar Grove: An Interdisciplinary Investigation of a Late Caddo Farmstead in the Red River Valley. Arkansas Archeological Survey Research Series No. 23, Fayetteville, Arkansas.

USDA, NRCS (United States Department of Agriculture, Natural Resources Conservation Service)

2016 The PLANTS Database. United States Department of Agriculture, Natural Resources Conservation Service, National Plant Data Team, Greensboro, NC 27401-4901. http://plants.usda.gov. Accessed $7 / 26 / 16$.
Vines, Robert A.

1960 Trees, shrubs, and woody vines of the Southwest. University of Texas Press, Austin.

Walker, Chester P., and Duncan P. McKinnon

2012 Exploring Prehistoric Caddo Communities through Archaeogeophysics. In The Archaeology of the Caddo, edited by Timothy K. Perttula \& Chester P. Walker, pp. 177-208. University of Nebraska Press, Lincoln, Nebraska.

Walker, Chester P., and Timothy K. Perttula

2008 Geophysical Investigations on Caddo Sites in East Texas and Surrounding States. Bulletin of the Texas Archeological Society 79:159-176.

Webb, Clarence H.

1959 The Belcher Mound: A Stratified Caddoan Site in Caddo Parish, Louisiana. Society for American Archaeology 16.

Wedel, Mildred Mott

1978 La Harpe's 1719 Post on Red River and Nearby Caddo Settlements. The Texas Memorial Museum Bulletin 30.

Wheeler, Elizabeth A.

2011 InsideWood - A Web Resource for Hardwood Anatomy. IAWA Journal 32(2):199-211.

Whitehead, William T.

2004 Maize Measurement Guide used by the Berkeley Paleoethnobotany Lab. McCown Archaeobotany Laboratory Reports. University of CaliforniaBerkeley.

Wood, W. Raymond

1963 The Denham Mound: A Mid-Ouachita Focus Temple Mound in Hot Spring County, Arkansas. Anthropology Series No. 1. University of Arkansas Museum, Fayetteville, Arkansas. 